\title{
DYNAMIC GOVERNMENT OF INDIGENOUS VILLAGE IN SOUTHEAST MALUKU
}

\author{
Stefie Hendric Alexander Laimeheriwa ${ }^{1}$ \\ Ella Wargadinata ${ }^{2}$ \\ ${ }^{I}$ Pemerintah Provinsi Maluku \\ Jalan Raya Patimura No. 1, Ambon, Maluku, Indonesia \\ ${ }^{2}$ Institut Pemerintahan Dalam Negeri (IPDN) \\ Jalan Ir. Soekarno KM 20, Jatinangor, Sumedang, West Java, Indonesia. \\ Correspondence Email: stefiehendric@gmail.com
}

Submitted: July 04, 2019, Reviewed: January 01, 2020, Accepted: January 10, 2020

\begin{abstract}
Research interest in the area of the governance traditional system in modern society is always interesting, especially for Indonesia which was set up above hundred of ethnic groups. The regime shifting gave an impact on the changes of village government policy. It was impact to almost traditional-village government in Indonesia which transformed into formal-village as National government structure version, although traditional values are still used and mixed therein.. Ohoi is a traditional village in southeast Maluku is one of an example on this compund model. The paper aimed to exlpore the dynamics of Ohoi institutional change sociologically, economically and politically based on evolutionary social change theory.The study used a qualitative phenomenological approach with informants consisting of Ohoi's stakeholders. The results showed that the Ohoi structure changes according to national government policies, however it does not change the social and political value system which is preserving in the Ohoi government system.
\end{abstract}

Keywords: Traditional-Value, Decentralization, Social-Bonding, Modern-Government

\begin{abstract}
ABSTRAK
Penelitian atas eksistensi desa adat di jaman modern, selalu menarik untuk dikaji, terutama di Indonesia yang dibangun dari berbagai budaya yang memiliki karakterikstik yang berbeda. Perubahan rejim selalu memberi dampak pada perubahan kebijakan pemerintah adat desa. Perubahan yang terjadi menjadikan sebagian besar desa di Indonesia telah bertransformasi menjadi lembaga formal versi pemerintah walaupun nilai tradisional masih dipakai dan bercampur didalamnya. Ohoi adalah salah satu desa adat di Kabupaten Maluku Tenggara yang bisa dijadikan model campuran ini. Berdasarkan Hukum Adatnya Ohoi adalah salah satu desa adat di Maluku Tenggara yang masih bertahan sampai saat ini eksis di tengah sistem pemerintahan modern. Penelitian ini berusaha untuk menggali dinamika kelembagaan Ohoi secara sosiologis, Ekonomi dan Politik dengan menggunakan teori evolusi perubahan sosial. Penelitian menggunakan pendekatan kualitatif fenomenologi dengan Informan terdiri dari pemangku kepentingan Ohoi. Hasil penelitian menunjukan bahwa struktur Pemerintahan Ohoi mengalami perubahan sesuai kebijakan pemerintah nasional di tingkat pusat, namun tidak merubah sistem nilai sosial dan politik yang berlaku dalam pemerintahan Ohoi.
\end{abstract}

Kata kunci: Nilai Tradisional, Kebijakan Desentralisasi, Keterikatan sosial, Pemerintahan Modern 
Vol..6, No.1, 2020

Doi: https://doi.org/10.24198/cosmogov.v6i1.22292 http://jurnal.unpad.ac.id/cosmogov/index

\section{BACKGROUND}

Research on the existence of indigenous villages consisting of traditional community groups that still maintain and are firmly bound by the traditions of their ancestors in the middle of the modern age are always interesting to study. The phenomenon of indigenous struggle groups that have different traditions from modern values is a phenomenon that occurs in many countries, studies on 'collisions' or 'crossing' as well as acculturation between traditional culture - modern life that occurs between these groups illustrate the surprising results. Rowland's study (2009) illustrates how tribal groups in Jordan try to maintain traditional genealogical democracies that are contrary to the principles of modern democracy. Then, the contradiction between the values of modern democracy and traditional traditions also occurs in Africa (Jalata, 2012). Blurred portraits of marginalized indigenous groups in the hustle and bustle of the modern government system revealed to occur in many countries, such as in Bolivia, Guatemala (Inguanzo, 2011) Indian tribes in Canada (Turpel, 1992), also occurring in India (Sahu, 2014) and also indigenous groups in several regions in Indonesia (Bebbington, Dharmawan, Fahmi, \& Guggenheim, 2004: Buttenheim \& Nobles, 2009: Antlöv, Wetterberg, \& Dharmawan, 2016: Henley \& Davidson, 2008).

The Indonesia Government recognizes the existence of customary normative villages more strongly. Cultural values handed down from generation to generation in the administration of Government in several traditional villages in Indonesia are still preserved and can be found amid the administration of modern governance today. Research on Ohoi from a sociological perspective has carried out, but not many studies have examined Ohoi from the standpoint of government science. Changes in policy on the administration of village governance which is regulated by the central Government indeed significantly affect the current Ohoi village governance.

Indonesia's Government formed from a combination of different village government systems. In general, local governments in Indonesia were initially in the form of kingdoms. They merged into a modern state called Indonesia and recognized national law as the law in force in their respective regions. The history shows that some regions still apply dualism in the government system, use the national system and also apply a limited traditional government system in their respective regions. Some regions still show secure attachment to traditional cultural customs, such as Bali, West Sumatra, and Yogyakarta. Research on 'restoring village rights to traditional village governance' is a fascinating study. The tug-of-war between the adoption of a custom-based village government system with a modern government system in Indonesia has occurred since Indonesia's independence. The traditional village which operates a system of Government based on law and local values that have forced to become a modern village since 1945 then has been changed back to a village-based on traditional values since 2016 by law (Antlöv et al., 2016).

The research was carried out in Ohoi (traditional village) in Southeast 
Vol..6, No.1, 2020

Doi: https://doi.org/10.24198/cosmogov.v6i1.22292 http://jurnal.unpad.ac.id/cosmogov/index

Maluku Regency, which until now still adheres to the system of administering its government on the order of common values inherited from its ancestors. Governmental research related to the village much focused on the implementation of the Village Autonomy. As Research I Gusti Ngurah Supartha D (2012) on: "Autonomy of Pakraman Village in the Implementation of Village Government in Bali" which is more focused on discussing the political dynamics of regional and village law. In contrast to this research which focused on looking at the impact of national government policies to 'regulate' traditional villages into exciting studies to be carried out in Ohoi-adat villages in Southeast Maluku that still use traditional governance systems, to what extent modern-traditional governmental inflation-acculturation occurs in Ohoi

Ohoi is one of the traditional villages located in the Kei Islands, Southeast Maluku in eastern Indonesia that still shows strong ties to their customs (Barraud, 1985; Hooe, 1990: Laksono, 2016: Kudubun, 2017). These traditional customs are institutionalized not only in cultural and social behaviour, but they reflected in their government systems. The Ohoi government system based on their traditional law called Larvul Ngabal (Soselisa HL, Sihasale WR, Soselisa PS, Litaay SCH, 2013).

The research uses the theory of the evolution of social change (Young, 1999). Young explained that each social group would have a unique institution that is following the values adopted by 'different societies have different institutions'. This institution is living in a dynamic environment that is not empty; therefore, any external changes will affect the internal system that runs slowly but surely. Young refers to this process of change as 'adaptive play' which illustrates how changes in internal systems respond to external changes to obtain an equilibrium, equilibrium position. This approach used to illustrate how changes in Ohoi's structure are moving slowly according to changes in central government policy towards village institutions. This paper uses three dimensions, namely social, economic and political to describe the factors that influence the dynamics of Ohoi's change.

\section{METHOD}

This study uses a phenomenological qualitative approach. Bertens (1981) said that a descriptive and introspective analysis of the depth of all forms of consciousness and direct experience (Bagus, 2002). The study conducted during the period January-April 2017. The location of the study was in Southeast Maluku Regency, which focused on three villages, namely: Letman Village, Rumat Village and Langgur Village. The selection of the location of this study made by purposive sampling based on the results of the Village Building Index measurement conducted by the Ministry of Villages in 2015. The three villages represent the status of the village based on classification. Letman Village represents a very underdeveloped village. Rumat represents the under-developed village, and Langgur represents the village Up. Informants in this study consisted of Head of the Southeast 
Vol..6, No.1, 2020

Doi: https://doi.org/10.24198/cosmogov.v6i1.22292 http://jurnal.unpad.ac.id/cosmogov/index

Maluku Regency Community and Village Empowerment Agency; Kei Kecil and West Kei Kecil Sub-Districts, Southeast Maluku Regency, Village Head and Village Apparatus, Kepala Saniri. Village Community Leaders. Kei legendary figure, Village Community The instrument used was interview guidelines, daily notes and transcripts. Data collection was carried out through in-depth interviews with informants, conducting FGDs with various related parties, as well as direct observation in the research locus villages.

\section{RESULT AND DISCUSSION}

The Southeast Maluku region during the Dutch colonial period included in the form of "Recht Streek Bestuurde Gebieden" which was headed by "Hooft Van Plaasselyk" as the Head of the Local Government. In 1948 Southeast Maluku, whose capital was Tual, was named "Onder Afdeling Kei Eenlanden" headed by the Resident Assistant. During the independence era, the formation of the Southeast Maluku Regency based on "Government Regulation Number 35 of 1952 concerning the Dissolution of South Maluku and the Establishment of the Central Maluku and Southeast Maluku Regions" and Law Number 60 of 1953 concerning the Formation of Level II Autonomous Region in Maluku Level I Autonomous Region (Statute Book Number 1118, Supplement to Statute Book Number 1645). The basic rules above form Southeast Maluku Regency as one of the oldest regencies in Maluku Province with the fullest administrative area stretching along the southeastern region of Maluku
Administratively, Southeast Maluku Regency now divided into 11 subdistricts, including:

1) Kei Kecil District with 15 Ohoi and 1 Kelurahan;

2) Kei Kecil Timur District with 18 Ohoi;

3) Kei Kecil Barat District with 10 Ohoi;

4) Kei Kecil Selatan Timur with 11 Ohoi;

5) Manyeuw District with 9 Ohoi;

6) Hoat Sorbay District with 13 Ohoi;

7) Kei Besar District with 37 Ohoi;

8) Kei Besar Utara Timur sub-district with 30 Ohoi;

9) Kei Besar Selatan District with 10 Ohoi;

10) Kei Besar Utara Barat District with 25 Ohoi; and

11) District of Ke Besar Selatan Barat with 13 Ohoi..

At the beginning before the formation of Ohoi (Village), the Kei community lived in the form of a family group (Klen), but gradually each of the more numerous clans finally chose to form Ohoi or the village. The Ohoi form evolved following changes in civilization in the Kei community, in the first period the form of the Kei community in the form of caves to shelter under the rock arbis sous roches. In the middle to the end, the form of their village was in the form of a large stage house, and surrounded by a fence made of stone (it is called Lutur).

Ohoi is an organization that unites various Faam and social strata. They have a system of life in carrying out their daily life in the village in the form of adats, such as death, birth, house construction, garden management, social functions, cooperation (Maren), determination of roles and functions social in society, and the Ohoi 
Vol..6, No.1, 2020

Doi: https://doi.org/10.24198/cosmogov.v6i1.22292

http://jurnal.unpad.ac.id/cosmogov/index

leadership process. All of these systems are driven and monitored by traditional institutions formed in Ohoi.

Even though Ohoi still adheres to traditional values, it has a characteristic modern government structure. It is indicated by the structuring of the local government, which has an explicit level and division of tasks, in the government of Ratshap, Ohoi, and Ohoi Soa. The three levels of government, according to Lor's grouping above existed long before the Indonesian government formed a nonaligned movement and the formation of groups of countries based on territories and interests as they are today.

The position of Ratshap as an essential part of the government which described in the two large Kei community above administratively the regional government has been divided into two administrative regions, namely Southeast Maluku Regency and Tual City. However, in adat government, Ratshap can still control and control the Ohoi people who are in its territory, even people who have migrated everywhere. The traditional government in the Kei community, as explained above, divided into three layers of government, namely: Ratshap, Ohoi and Ohoi Soa.

The term ratshap, when traced in the etymological perspective of the word, comes from the Dutch language, which introduced in the colonial era of the Dutch East Indies. Therefore, it can be ascertained, Ratshap is the name given by the Dutch, which shows understanding in a territory that is headed by a Raja (Rat) together with his traditional institution. Ratshap as an indigenous community unit that is independent in regulating and deciding the traditional problems faced in the Ohoi / Ohoi Rat environment, which is under the authority of Ratshap.

The appointment of the King in the Kei Society is closely related to the desire to expand the group territory between Ursiw and Lorlim and the mission of spreading the Larvul Ngabal Law, the strategy used in the appointment of the King to the ancient Kei community following oral and speaking traditions ended in 1939. When we examine in depth the process of appointing the King in the Kei community which proceeded at that vulnerable time did not rule out the possibility of involving the colonial rulers of that era who had been in power since 1645. It also supported by Ohoitimur's explanation which said that: "The title of King in Kei society must be connected with the existence of the Dutch Government, even though the Kei people have had a tradition in appointing kings far before. " Ratshap was formed as part of the delegation of authority to overcome various problems that occur in the Kei community which considered to be very broad and complex, thus illustrating the representation of adat institutions in the decision-making process.

\section{The Dynamic of Ohoi's Government}

In the post-independence Indonesian Government system, the changes that occurred in the village became the primary embryo for the formation of a national government. These can found in a speech outlined by Soepomo about the Republic of Indonesia regarding the position of the village as a "Village 
Vol..6, No.1, 2020

Doi: https://doi.org/10.24198/cosmogov.v6i1.22292 http://jurnal.unpad.ac.id/cosmogov/index

Republic" based on state theory (Ni'matul, 2015 ). In essence, Indonesia formed by an accumulation of villages. It formed by communities that have the same purpose and direction of life.

Soepomo's view above refers to a state whose governance structure adapted to the original social structure of the Indonesian people, which is still maintained today, namely the village. Soepomo's view above also has good reasons because long before the Dutch Indies government controlled the archipelago. The village has an independent social structure, as expressed by Van Vollenhoven (Syarifudin, 1976).

Van Vollenhoven's explanation proves that the Nusantara already has a complete government structure. The structure includes the Constitutional Law, Institutions that carry out governmental tasks, and the democratic process at the village level. It happened even before other countries colonized Nusantara. Regarding Van Vollenhoven's explanation above

The village at that time was recorded in 1817 on June 14 in a report submitted by Mutinghe to GovernorGeneral Thomas Stamford Raffles relating to the existence of villages on the northern part of Java Island which had robust ties in their population (Kartohadikoesoemo, 1984)..

The Indonesian government's policy to strengthen by restoring the role of traditional villages to organize governance within the jurisdiction, on the one hand, is welcomed. This policy shows, the seriousness of the Government of Indonesia to recognize the existence of indigenous villages that existed long before the State of Indonesia formed. It also shows that the state recognizes that there are Indonesian people who are still firmly bound by traditional policies handed down from generation to generation from past centuries. However, this policy also viewed with scepticism. It is because the power of traditional villages in this modern era has experienced many changes. The reality is seen from traditional villages now is only a small part of the greatness of traditional villages in the past century. The current customary village is a customary village that has undergone an institutional change in value caused by many influences. Institutional changes in villages in Indonesia can at least seen from 3 aspects of village development, namely: sociological, economic and political meanings.

\section{The Sociological Perspective}

From a sociological perspective, the village is a form of community unity in the community, related to interactions between individuals in the community and with the surrounding environment, has a harmonious relationship, and depends on the virtues of nature. In this sociological perspective, Ohoi has a whole picture of the harmonization of life through the philosophies of life that have become part of the traditions and culture of the Kei community. In its dynamics, Ohoi has a dependency on nature. It had shown from the harmonization of life with nature, with the tradition of Sasi (Hawear Balwarin) as a form of consistency in protecting and caring for the natural environment.

The process of customary Ohoi governance in the Kei community has long 
Vol..6, No.1, 2020

Doi: https://doi.org/10.24198/cosmogov.v6i1.22292 http://jurnal.unpad.ac.id/cosmogov/index

had a structure and function in indigenous peoples that began with the social stratification of the community and adopted in the Ohoi and Ratshap governance structures and functions. The division of tasks carried out in clans / faams that have occupied social functions in the kei community, namely: Mel-Mel, Ren-ren, and Iri-ri in Ohoi. Mel-mel gets the job of being the leader of Ohoi and Ratshap, while Ren has the duty of being the Landlord (Mr. Tan), and Iri has the duty of being a maid. Besides, the Kei community has an overall internal structure, including 1). Rinrahan, also known as the Small Household/family alliance. 2). Rahanyam which is a collection of several Rinrahan (Matarumah). 3). Ohoiraut (the alliance of some Rahanyam formed into Desa / Ohoi. 4). Lor or Ur, which is a group that is a partnership of several Ohoiraut in the form of Rat (Pattikayhatu et al., 1978). In the past, the Kei island community was still categorized as a close society, this pattern which formed an integral cultural identity of the Kei society era because it has not been affected by modern times.

The sociological perspective also associates the village as a legal community unit or community group that has autonomy as a form of appreciation. It is because the village seen as the first power organization that grows to be as large as a kingdom without gifts from other parties, which looks like modern countries today. The village has its authority to determine the direction of change. As a tangible form of a village, people who considered to have been independent life together and embrace the same culture.
Sztompka says, ontologically, that society cannot be in a constant state always because all social realities will continuously change according to different degrees of speed, intensity, rhythm, and tempo (Sztompka PiÖtr, 2004). Communal village life systems are characteristic of village typologies, namely the community that all resources have an essential role in the dynamics of village community communities both in the social and economic aspects of the village and even the political aspects of the village. In order for everything to go well, the assumption is that the critical role of the village social system, such as kinship, kinship, and solidarity.

\section{The Economic Perspective}

From the economic aspect, the village as a community unit seeks to fulfill its daily life from the availability of the natural world around it. The village as an economic unit where the villagers try to meet their needs through economic activities that are adjusted to the potential of the village, such as farming, raising livestock, cutting down forests, and going fishing to fish, weaving. Activities, as mentioned, are claims of rural economic activity.

Awareness to have an income for sustainability in the Kei community began in 1870 when the Nederlandsche OostIndische government implemented policies to guide and assist Kei residents towards higher civilizations by exploiting industry, trade and order opportunities. Efforts to generate income for the Kei community began at the time the tax imposed for people aged 16 years and older of 1 guilder 
Vol..6, No.1, 2020

Doi: https://doi.org/10.24198/cosmogov.v6i1.22292

http://jurnal.unpad.ac.id/cosmogov/index

or equal to 100 coconuts (Thorburn, 2005). It has an impact on people who start trying to sell their natural products to obtain income that used to pay taxes.

\section{The Political Perspective}

It understands the village from a political perspective as an organization of power that has absolute authority as part of the government system of the Unitary Republic of Indonesia to decide everything under the interests of the legal community concerned as a logical consequence of ownership of the original Autonomy. Ohoi's original autonomy framework, which is still part of Ohoi's political culture, is illustrated by the appointment of the Head of Ohoi (Orang Kay) through a paternalistic lineage. The environment of evolutionary change will significantly influence the political framework. This influence will have a direct impact on society, such as Boon and Geralding's view that: "When political leadership changes in response to societal changes in values and preferences, there would be pressure to reexamine the institutional framework prevalent under previous political regimes. " (Boon and Chen, 2007)

The initially small village then grows and develops to become larger, so that the desire to expand power is born as a sense of confidence in the power it has. Sometimes the desire to expand the power to the extent carried out through warfare and other political tactics. It also happened in ancient Kei society to expand the territory of power. Raja Tebtut ordered his son Dithe sak Mas to marry Hilla'I Arnuhu Suarubun in Danar, a native of the Kei Islands. It is a form of political expansion of the expansion of its territory, which centered in Ohoivuur. The expansion of power carried out by the Tabtut became the first step in the tradition of the appointment of the king in ancient times in Kei society where there was competition for the expansion of power between the Ursiw group so that it became 10 Kingdoms and the Lorlim Group also became 10 Kingdoms. The formation of the kingdom (Ratshap) last carried out in 1939; namely, the insistence of the people to break the kingdom of Lo Ohoitel (Nerong) eventually became the Kingdom of Nerong and the kingdom of Ub Ohoifaak (Ohoitimur Yong, 1983).

The structure underwent changes that were influenced by the colonial government and migrants to the Kei Islands. The influence of immigrants and affiliated with residents and entrusted to be a leader is what shifts the development of Ohoi-Ohoi towards the coast and experiencing a growth in numbers (Thornburn, 2005)

The leaders who come from these migrants, along with the indigenous people, are in a relationship of blood ties through drinking each other's blood (Kudubun, 2017: Kudubun, 2017). This Kei community, as described by the Comte, as a human biological organ that is interdependent to maintain its life in groups. Amid the dependency of the Kei community, they form their government system to become the community's guideline for survival, which continues to experience changes under the conditions faced.

The strength boundaries of Kei Society still maintained as part of the life 
Vol..6, No.1, 2020

Doi: https://doi.org/10.24198/cosmogov.v6i1.22292

http://jurnal.unpad.ac.id/cosmogov/index

and development of civilization. These can be found in the values, habits, arts, and customs of the local community as stipulated in the Larvul Ngabal Customary Law. The Kei people believed that their glory had existed long before the days of the major kingdoms in the archipelago, such as Srivijaya, Singosari, and Majapahit. Even, they believed before the entry of the hegemony of a vast kingdom in Nusantara, and the Kei kingdom had a complete social and government structure (Ohoira, 2016).

\section{The Dynamics of the Ohoi Government Structure Based on National Policy}

Ups and downs in the current condition of the village are inseparable from the inheritance received by the village through various rules made by the supradesa government. This rule formed since the colonial era of the Dutch East Indies, which issued "Inlandsche Gemeente Ordonnantie" (IGO), which applies to the islands of Java and Madura and "Inlandsche Gemeente Ordonnantie Buitengewesten" (IGOB) which applies to outside of Java and Madura. During the Dutch colonial administration, villages still have given autonomy, but in economic aspects, they would adjust to the interests of the colonizers. The colonial rule has imposed money and energy on society. Whereas in the applicable regulations, the benefits are not only not understood by the community, but also the benefits are doubtful. The reality faced by the village is conflicting with village interests.

The colonial government did not directly regulate the development of Ohoi in Kei during the colonial era, which written through IGOB outside of Java.
However, in reality, the Kei community had used a conventional government system headed by Hillai. The customary alliances in the government, known as the Inlandsche Rechtgemeenschapen / even the smallest unit of society, were granted autonomy but also charged by the colonial government.

As evidence of interventions in customary governance in Kei, the Hilaai title as replaced with the title Rat (Raja) and Orangkaya. In the oral tradition that there were several appointments of the King symbolized by the surrender of objects as seals of friendship and kinship that were not the original goods of the kei community, for example. Cannon at the appointment of King Ibra and Tual (Ohoitimur, 1983). Another thing that found in the structure of government during colonialism was the similarity of nomenclature positions in the Ohoi government in Kei with the Government of the State in Central Maluku, for example, Kapitan, Soa, Saniri, and Marin (Ohoitimur, 1983).

In the era of Sukarno, the village did not have a legal force in Indonesia's governance until the new Order era in the year 1976 issues about the village has been a concern of several Parties at the national level discussing the critical view of village existence. In the view that was the focus of the discussion at that time, seriously reviewing the autonomy of villages, Village development to poverty, and the country's retardation. Three years after the discourse of the government realized the issue of the village in Law No. 05 of 1979 on village governance, but hopes dreamed of by village practitioners were answered 
Vol..6, No.1, 2020

Doi: https://doi.org/10.24198/cosmogov.v6i1.22292

http://jurnal.unpad.ac.id/cosmogov/index

upside down by the government. The substance of the regulation does not recognize, respect, and strengthen the autonomy of the village. Instead, it creates the destruction of the village, both structure and function of the village, particularly the unity of indigenous peoples.

The motive that undertook the uniformity through Law No. 05 the year 1979 about the village government, conducting village bureaucracy reform by moving the village community through national programs and organizing the village administration evenly and effectively. As a result, society's unity holding on the customs of the smallest unit, such as Hamlet, is eliminated. It due to combined with the mother village as an area that controls and controls all the resources it has.

Government recognition of the existence of the village should be able to raise the confidence of the villager's role in national development because it is considered a strong bond of togetherness. According to Soetardjo, however, strong ties in the community had not evenly distributed across entire islands. Such as Madura, Banten, and others, the population's ties had weakened. The highest level of village development in Indonesia at that time was in the area of Bali, Sumbawa Island, and in the Maluku region. In the Maluku region, although formed from the islands but has a powerful bond such as in the region of Ambon and Uliasser Islands, Kei Islands, Tanimbar Islands, Seram, and Pulau Buru (Ohoitimur, 1983). Strong ties of the Kei Islands community and the effective customary governance evidenced in the horizontal conflict that struck the province of Maluku in 1999 as a whole. The Supradesa government suffered a total paralysis in 3 months, the incident regarded by the Kei community is a calamity, just like other natural disasters. Many Kei people consider conflicts as a sign for them that many people no longer pay attention to the customary law that has been guarding the Kei community all this time. Customary law has become a way to end the conflict as well as become the patron of the Kei community for approximately five centuries. Even the new order government is very thick with centralistic.

After the reform in 1998, through UU No. 22 of the year 1999 and UU No. 32 the year 2004 concerning local government, Regent/city has authorities to govern the villages according to the right of the descent. By the authority owned by Southeast Maluku Regency, the local government issued regional Regulation No. 03 the year 2009 about Ohoi and Ratshap. Local regulations intended to protect and preserve the consistency of the application of the customary law of Larvul Ngabal. The level of a customary organizational structure under RATSHAP is Ohoi. Ohoi, also in the customary structure has the same role and function between each other. However, there are several different roles and functions that some Ohoi are caused by specificity because there are several factors such as history, a position as Ohoi Rat (Kampung Raja), and characteristic territorial territory. The structure of the Government of Ohoi changed, combining the customary structure with a structure mandated in the local regulation number 03 
Vol..6, No.1, 2020

Doi: https://doi.org/10.24198/cosmogov.v6i1.22292

http://jurnal.unpad.ac.id/cosmogov/index

the year 2009 about Ohoi and Ratshap

article

paragraph

2.

Scheme 1. Organization of Ohoi according to Peraturan Daerah Kab. Maluku Tenggara No.03/2009

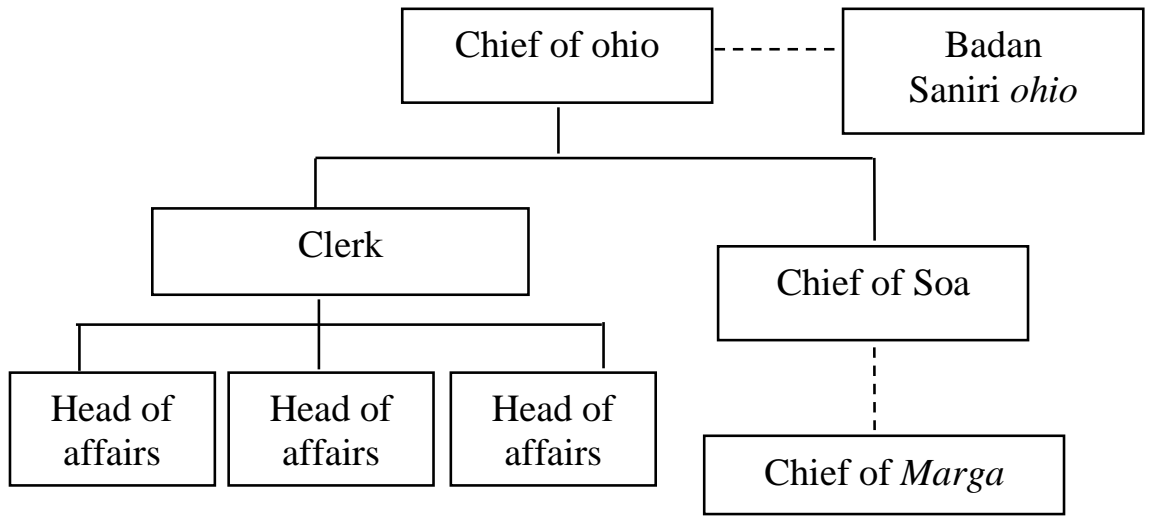

Sumber: Soselisa dkk. 2013:36

The adjustment of structures performed at the time of reform with the recognition principle of the prevailing rules does not necessarily return Ohoi to the original structure; in the picture above, the structure that was changed only in the Village Society Institute only changed with the Saniri Ohoi agency. This agency functionally as a representative institution of Ohoi, and also a representative number of Marga Ohoi in government, which is represented in ex officio by the head of Marga. The position of the body of Saniri Ohoi and the head of Marga in the structure had an ambiguous position. On one side, the head of Marga is under the head of Ohoi and the head of Soa. However, another side as the Saniri, with the head of Ohoi running the government.

The institutional changes that occurred in Ohoi's reign over time were an additional condition as a consequence of the political change from Ohoi's dependence on Supradesa as an option in the face of change.
Studying the current condition of the village deeply, in the context of the governance of the village, is experiencing a period of transition from the substantive administrative model to the formal administration model. The substantive administrative model refers to the Living ordinance of the community that maintains a public service redistribution mechanism for the public carrying out a tribute payment obligation to its leader "King" and will forward to the government officials. While as formal, the government is a "bureau" consisting of bureaucrats as policy implementation. Although the process of village governance now requires the transition process to be done, the process still takes time because the traditional system position is still a part of community life. All applicable laws and regulations do not clarify the authority of Ohoi as a social entity in the implementation of customary governance in the middle of the genealogical Kei community that has the Self-Governing Community governance system. The ideas associated with village 
Vol..6, No.1, 2020

Doi: https://doi.org/10.24198/cosmogov.v6i1.22292

http://jurnal.unpad.ac.id/cosmogov/index

involvement in the government broadly designed to be contextually planned in the technical policy to accommodate all parties, so that the policy of being born has proper respect from society (Boon and Chen, 2007).

The dynamics of the Ohoi government described above in general Ohoi has undergone many changes. Changes that occur in Ohoi occur in various segments of life, such as population numbers, Ohoi's position, socio-cultural and political status, and economic conditions. The dynamics that occur in Ohoi are still not relevant and are useful in adjusting themselves to the needs because all policies are supradesa government decisions that have not yet taken the form of innovation. The changes made have not accommodated the needs and expectations of the Ohoi indigenous people, which contain new ideas in developing traditions with innovative approaches. The real effort that could do in the Kei community's life is to keep the wisdom that they have, so that common symbols stay alive such as Woma (Ohoi's central symbol), social customs and interactions, kinship relationships in a shared life.

This condition illustrates the implementation of moral conduct, which illustrates the fact that moral values recognized as cultural values, which must encompass community life. These are the community's efforts to maintain the values of character that believed to be a simple measure of the community fighting for the rise of Kei culture as a legacy filled with wisdom and human values. Villages to their autonomy and democracy have been under pressure from the logical consequences of the village's position as self-local governance in terms of science, policy, and advocacy in the form of village renewal issues. The village's renewal oriented towards the future of a developed, independent, and democratic village, to realize all of these needs to pay attention to two critical dimensions.

First, moving from experience, where Ohoi reflects the structural destruction of Ohoi's life as a result of the uniformity of structure as the smallest part of the national governance system. Paradigmatically, the issue of village renewal, which is also a result of reflections on modernity that oriented to the development process, begins with a deep concern for villages in developing countries experiencing many inequalities, gaps in funding, and various discrimination received from the regions and the government.

Second, village renewal is seen as a transformation to achieve a better village in all aspects of life, both social, economic, and environmental, through social movements of all parties. The transformation carried out in the village must be based on sustainable development. Massive social movement collaboration will make a real contribution to the transformation of the village. 
Vol..6, No.1, 2020

Doi: https://doi.org/10.24198/cosmogov.v6i1.22292

http://jurnal.unpad.ac.id/cosmogov/index

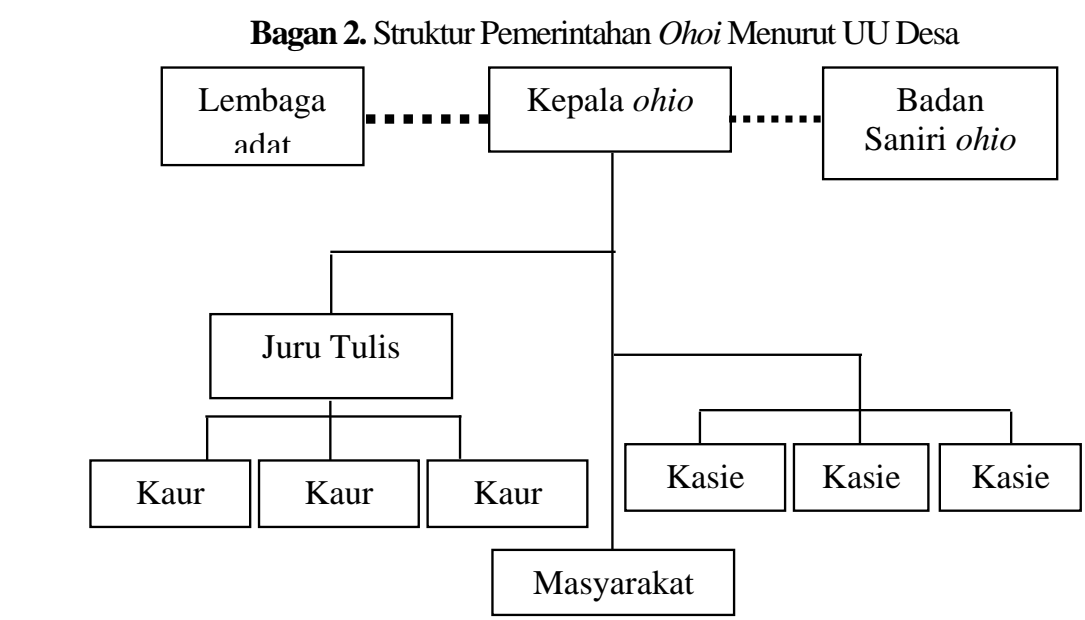

Sumber: Lampiran Permendagri 84 tahun

2015

The conditions experienced by Ohoi in Southeast Maluku Regency that could saw that in the context of social institutions for Ohoi which located far from urban areas, the traditions and customs are still very clear, different from villages in urban areas, social institutions will only move when problems occur problems related to adat. In the process of organizing the dynamics of governance that occurs in Ohoi outside the urban area, merely the structure of the Ohoi apparatus that adjusts to formal rules while the conventional apparatus stands alone as other parts that have an essential role in the problems there. The separation of Ohoi government structure and adat only happened to Ohoi Rat. The reason for maintaining the authority of the king in the scope of the Ratshap was that an Ohoi head led the administration of the government in Ohoi Rat, this was a formal consequence of the issuance of Regional Regulation 03/2009 concerning Ohoi and Ratshap.

As a consequence of the government policy change on village governance, the Ohoi government structure described above must adjust to formal rules while awaiting the revision of regional regulations on Ohoi and Ratshap, which temporarily discussed between the regional government and the Southeast Maluku Regency People's Representative Council. Following the direction of the discussion, the Ohoi government structure will change by separating the village representative body and the traditional institutions that deal with adat issues (Laksono, 2016).

\section{Analysis of the Drivers of Ohoi Institutional Dynamics.}

The dynamics of the Ohoi government that has occurred to date, as described above, is a description of theoretical and empirical complexity. Empirically, the structural conditions of the Ohoi government, as the dynamics above, have the most significant role in local government through policies, the lack of input from the lower reaches accommodated in policy formulation creates a mismatch between the sociocultural conditions of Ohoi and the policies that have issued to enliven supradesa. The 
Vol..6, No.1, 2020

Doi: https://doi.org/10.24198/cosmogov.v6i1.22292 http://jurnal.unpad.ac.id/cosmogov/index

main problem that occurs is Ohoi's position as an autonomous region that has the right to regulate and manage its government following the prevailing traditions and customs, which are ruled out by the supradesa government. Whereas Ohoi autonomous as a common area is a form of moral responsibility that is not related to strategic issues but is related to spiritual responsibility, which is not only related to the interests of the state but also the interests of individuals in a communal system (Kartohadikoesoemo, 1984).

Based on the above discussion, changes that occur in Ohoi could identify several factors. First, being modernization, which can significantly change the face of community life (Huntington, 1971). Second, the change in the face of customary village governance influenced by government policies on villages that began in the Dutch colonial era to the era of Indonesian independence. During the Dutch colonial administration, the village government regulated as a government entity that had to participate in the Dutch system of government. This policy created a hierarchical relationship structure that led to the emergence of supra-village institutions outside the local government structure (Soselisa HL, Sihasale WR, Soselisa PS, Litaay SCH, 2013; (Kholifah, 2013).

Third, the state's intervention in the village government's administration became more robust when Indonesia gained independence in 1945. During independence, the national government understood how important villages were in the context of the unitary state of the Republic of Indonesia so that they re outlined in the 1945 Constitution outlined in article 18 of the 1945 Constitution The village regulation s stipulated through Law number 22 of 1948 concerning Regional Government which makes the village as a subordinate of the Regional Government as a level III Autonomous Region. Law Number 05 of 1979 concerning Village Government, which is a product of the New Order, shows village governance without regard to the diversity and traditional governance systems they have.

Fourth, the policy of recognition of the existence of villages, when Indonesia entered a new round of governance in 1999. The regime that declared an era of 'reform.' The peak of government support for the reform era occurred in 2014 when the Government of Indonesia issued a village law that wholeheartedly acknowledged all the specialties that were owned by the village. The state firmly recognizes the authority of indigenous villages and gives full authority to implement an autonomous system of government as long as it does not conflict with state policy. In 2014, with the issuance of Law No. 6 of 2014 concerning Villages becoming a stepping stone to truly make villages a subject of development following the values that develop in them, following the mandate of Article 4.

\section{CONCLUSSION}

Looking at changes in the structure and function of Ohoi/village government in an institutional context, it is not easy to separate them from the historical approach from postcolonial to the present. The history of the village administration, which has always changed to adjust to the 
Vol..6, No.1, 2020

Doi: https://doi.org/10.24198/cosmogov.v6i1.22292 http://jurnal.unpad.ac.id/cosmogov/index

dynamics of conditions and the national political situation. The dynamics of Ohoi Structural changes that are driven by factors of modernization, factors of governance change, as a form of intervention factor of the superstructure government through the national recognition policy factor do not directly change the prevailing value system of Local Wisdom that comes from the Larvul Ngabal customary law. Besides, Ohoi, as a community united with the power of Kinship, makes the value system built strong and able to survive during change that hit Ohoi.

\section{REFERENCES}

Antlöv, H., Wetterberg, A., \& Dharmawan, L. (2016). Village Governance, Community Life, and the 2014 Village Law in Indonesia. Bulletin of Indonesian Economic Studies. https://doi.org/10.1080/00074918.2 015.1129047

Bagus, Lorens. (2002). Kamus Filsafat. Jakarta: Gramedia Pustaka Utama.

Barraud, C. (1985). The Sailing-Boat: Circulation And Values in the Kei islnads,in context and levels,Anthropological and essays on Hiperiodrchy in Indonesia. Jaso Occasional Papers, 4.

Bebbington, A., Dharmawan, L., Fahmi, E., \& Guggenheim, S. (2004). Village politics, culture and community-driven development: Insights from Indonesia. Progress in Development Studies. https://doi.org/10.1191/146499340 4ps085oa

Boon and Chen. (2007). Dynamic Governance, Embedding Culture, Capabilities and Change in Singapore. World Scientific Pub Co Inc.

Buttenheim, A. M., \& Nobles, J. (2009). Ethnic diversity, traditional norms, and marriage behaviour in Indonesia. Population Studies. https://doi.org/10.1080/003247209 03137224

Henley, D., \& Davidson, J. S. (2008). In the name of Adat: Regional perspectives on reform, tradition, and democracy in Indonesia. Modern Asian Studies. https://doi.org/10.1017/S0026749 X07003083

Hooe, T. (1990). Little Kingdoms, adat and inequality in the Kei Islands, Eastern Indonesia.

Inguanzo, I. (2011). Indigenous Peoples, Democracy, and Representation: The Cases of Bolivia and Guatemala. Boletin PNUD \& Instituto de Iberoamerica, (February).

Jalata, A. (2012). Gadaa (Oromo Democracy): An Example of Classical African Civilization. Sociology Publications and Other Works. Retrieved from $\mathrm{http} / / /$ trace.tennessee.edu/utk_soco pubs $/ 80$

Kartohadikoesoemo. (1984). Desa.

Kholifah, E. (2013). Pengaruh Otonomi dan Pemberdayaan terhadap eksistensi desa adat: Studi di Desa Tengganan Kecamatan Manggis Kabupaten Karangasem Bali, (Impact of decentralization on indigenous Village: Study in Tengganan Village-Bali). Politico, 1.

Kudubun, E. (2017). Ain Ni Ain, Kajian Sosio-Kultural Masyarakat Kei Tentang Konsep Hidup Bersama dalam Perbedaan (Ain Ni AinStudy Socio-Cultural on Kei Community about Living unity in diversity). Cakrawala, 163-189.

Laksono, P. (2016). , The Adat contributions for the villages to develop independently: case from the Kei Islands, Southeast Maluku Regency. Humaniora, 28(3).

Ni'matul, H. (2015). Hukum pemerintahan Desa. Hukum pemerintahan Desa.

Ohoira, A. (2016). Kei (Alam, Manusia, Budaya dan beberapa Perubahannya),. Yogyakarta: Sibuku. 
Vol..6, No.1, 2020

Doi: https://doi.org/10.24198/cosmogov.v6i1.22292

http://jurnal.unpad.ac.id/cosmogov/index

Ohoitimur, Y. (1983). Beberapa sikap hidup orang Kei: Antara ketahanan diri dan proses perubahan, suatu studi antropologi budaya nasional. Sekolah Tinggi Seminari Pineleg.

Pattikayhatu dkk. (1978). Sejarah Pemerintahan adat di Kepulaauan Kei Maluku Tenggara. Ambon.

Rowland, J. (2009). Democracy and the Tribal System in Jordan: Tribalism as a Vehicle for Social Change. Independent Study Project (ISP) Collection. P.

Sahu, K. K. (2014). Challenging Issues of Tribal Education in India. IOSR Journal of Economics and Finance (IOSR-JEF), 2(3), 48-52. Retrieved from www.iosrjournals.org

Soselisa HL, Sihasale WR, Soselisa PS, Litaay SCH, N. T. (2013). , Studi Kelembagaan Masyarakat Lokal Kei Kecil Bagian Barat Kabupaten Maluku Tenggara, Analisis Kelembagaan Lokal Wilayah Tujuan Kawasan Konservasi Pperiodiran (Study on local community institution Western Kei Kecil-Southeast Maluku, Local Institutional a.

Syarifudin, A. (1976). Pengaturan Koordinasi Pemerintahan di Daerah. Bandung: Tarsito.

Thornburn. (2005). Musibah: Entitlements, Violence and Reinventing Tradition in the Kei Islands, Southeast Maluku,. Centre of Southeast Asian Studies.

Turpel, M. E. (1992). Indigenous People's Rights of Political Participation and Self-Determination: Recent International Legal Developments and the Continuing Struggle for Recognition. Cornell International Law Journal, 25(3), 579-602. Retrieved from http://scholarship.law.cornell.edu/ci lj/vol25/iss $3 / 6$

Young, H. P. (1999). Individual Strategy and Social Structure: An Evolutionary Theory of Institutions. Canadian Journal of Economics/Revue Canadienne D`Economique, 32(1), 247-250. https://doi.org/10.2307/136405 